\title{
PHYSICAL AND PHYSIOLOGICAL ATTRIBUTES OF NATIVE FOREST SEEDS AND THEIR INFLUENCE ON DIRECT SEEDING FOR RESTORATION OF CILIARY FOREST
}

\author{
Janisson Batista de Jesus ${ }^{1 *}$, Robério Anastácio Ferreira², Dráuzio Correia Gama ${ }^{3}$, Maria Fernanda Oliveira \\ Torres ${ }^{4}$ \\ 1*Universidade Federal do Rio Grande do Sul, Doutorando pelo Programa de Pós-Graduação em Sensoriamento Remoto, Porto Alegre, Rio \\ Grande do Sul, Brasil - janisson.eng@gmail.com* \\ ${ }^{2}$ Universidade Federal de Sergipe, Departamento de Ciências Florestais, São Cristóvão, Sergipe, Brasil - roberioaf@yahoo.com.br \\ ${ }^{3}$ Universidade Estadual do Sudoeste da Bahia, Mestrando pelo Programa de Pós-Graduação em Ciências Florestais, Vitória da Conquista, \\ Bahia, Brasil - drauziogama@ hotmail.com \\ ${ }^{4}$ Universidade Federal de Sergipe, Doutoranda pelo Programa de Pós-Graduação em Agricultura e Biodiversidade, São Cristóvão, Sergipe, \\ Brasil - nandatorres7@gmail.com
}

Received for publication: 28/02/2018 - Accepted for publication : 12/05/2020

\begin{abstract}
Resumo
Atributos físicos e fisiológicos de sementes florestais nativas e sua influência na semeadura direta para restauração de mata ciliar. O conhecimento da relação entre as características físicas e fisiológicas das sementes florestais é essencial para o sucesso dos projetos de recuperação das matas ciliares. Sendo assim, o trabalho foi realizado com o objetivo de analisar parâmetros físicos e fisiológicos de sementes de espécies florestais, para o uso na restauração de matas ciliares por meio de semeadura direta. Foram realizadas avaliações da qualidade física (teor de água, massa específica, peso de mil sementes e número de sementes por quilograma), morfométricas (comprimento, largura e espessura) e fisiológica em laboratório (viabilidade) de Cassia grandis L.f., Enterolobium contortisiliquum (Vell.) Morong., Guazuma ulmifolia Lam. e Libidibia ferrea var. leiostachya (Benth.) L.P.Queiroz. O experimento em campo foi implantado em Delineamento em Blocos Casualizados (DBC) com quatro blocos, testando-se as sementes tratadas para superação de dormência de quatro espécies. A semeadura direta foi realizada em 10 linhas de plantio, cada uma composta de 10 covas $(30 \times 30 \times 30 \mathrm{~cm})$, em espaçamento 2,0 × 1,0 m. Sementes de E. contortisiliquum apesar de terem os maiores valores para as características físicas e morfométricas e ter alto percentual de germinação, foi a espécie de menor percentual de emergência em campo, ficando abaixo de G. ulmifolia que tem sementes de menores tamanho e peso, e L. ferrea var. leiostachya que, mesmo tendo baixa germinação, foi a segunda de maior percentual de emergência. $\mathrm{O}$ estudo permitiu observar que não houve uma relação direta entre os atributos físicos e fisiológicos das sementes florestais e sua capacidade de emergência.

Palavras-chave: Espécies arbóreas; Qualidade de sementes; Germinação; Emergência em Campo Mata Ciliar.
\end{abstract}

\begin{abstract}
Knowing the relationship between the physical and physiological characteristics of native forest seeds is essential for the successful recovery of riparian forests. Thus, the work was carried out to analyze the physical and physiological parameters of seeds of native forest species for use in the recovery of riparian forests by direct seeding. Were evaluated the physical quality (water content, mass, the weight of one thousand seeds, and the number of seeds per kilogram), morphometric characteristics (length, width, and thickness), and physiological quality in the laboratory (viability) of Cassia grandis L.f., Enterolobium contortisiliquum (Vell.) Morong., Guazuma ulmifolia Lam., and Libidibia ferrea var. leiostachya (Benth.) LPQueiroz. The experiment in the field was implanted in a randomized block design (RBD) with four blocks, testing seeds treated to overcome the four species dormancy. The direct sowing was in 10 planting lines, each composed of 10 pits (30 x $30 \times 30 \mathrm{~cm}$ ), spaced $2.0 \times 1.0 \mathrm{~m}$. E. contortisiliquum seeds, despite having the highest values for physical and morphometric characteristics, and having a high percentage of germination, was the species with the lowest percentage of emergence in the field, being below G. ulmifolia, which has seeds of smaller size and weight, and L. ferrea var. leiostachya which, despite having low germination, was the second with the highest percentage of emergence. The study allowed us to observe that there was no direct relationship between the physical and physiological attributes of forest seeds and their ability to emerge.

Keywords: Tree species; Seed Quality; Germination; Field Emergence Riparian Forest.
\end{abstract}

\section{INTRODUCTION}

The germination of a seed is the result of metabolic processes, initiated from a greater intensification of the respiratory activity, resulting from the absorption of water, which degrades the reserve substances generating the consequent production of compounds rich in energy that allow the growth of the embryonic axis

FLORESTA, Curitiba, PR, v. 51, n. 2, p. 255-262, abril/jun 2021.

Jesus, J. B. et.al.

ISSN eletrônico 1982-4688

DOI: $10.5380 /$ rf.v51 i2. 58181 
(CARVALHO; NAKAGAWA, 2012), therefore, physiological studies are fundamental for understanding this process in different forest species, both in laboratory conditions and in fieldwork.

In Brazil, seed tests, such as the viability for plant species evaluation, occur according to the Seed Analysis Rules (BRASIL, 2009) and Instructions for Analysis of Forest Species Seeds (BRASIL, 2013) recommendations. Besides being fundamental to the physiological potential of the seed's knowledge, these analyzes offer information about the viability and vigor of the vegetative material analyzed (SILVA et al., 2014). It is also essential to obtain data on the external characteristics of seeds, such as shape, dimensions, and color, which are relevant factors that can assist in the propagation of different plant species (FLORES et al., 2014).

Because of the high need for degraded environments recovery, verified by the increase of these activities in natural ecosystems (SILVA et al., 2015), it is essential to understand the factors that interfere in the emergency process in the field, as fundamental for the successful use of sowing direct, as this is a technique widely applied for this purpose, especially when the objective is to reduce costs since it eliminates the entire seedling production phase in a nursery (SANTOS et al., 2012).

Therefore, the comparison of data in controlled laboratory conditions with field experiments is necessary, serving as a basis for forest restoration/restoration activities since, in the field, the conditions in which the seeds are in the soil are not always optimal for the emergency. In this sense, studies related to the germinative responses of seeds in artificial conditions should be carried out, making it possible to obtain information on the species ecophysiology and, still, as tools to evaluate the limits of tolerance of survival and adaptation of these species to the conditions of natural stresses (GUEDES et al., 2013).

Considering the reported aspects, this work was carried out to analyze the physical, morphometric, and physiological parameters of seeds of native forest species (Cassia grandis Lf, Enterolobium contortisiliquum (Vell.) Morong., Guazuma ulmifolia Lam. and Libidibia ferrea var. leiostachya (Benth.) LPQueiroz.) compared to the response via direct seeding for use in the recovery of riparian forests.

\section{MATERIAL AND METHODS}

The choice of these species was defined based on their natural occurrence in the riparian forests of the region and reconciliation with the availability of seeds in the cold chamber of the Federal University of Sergipe (UFS)'s Department of Forest Sciences.

The fruits of each species were harvested in the municipalities that make up the Piauitinga River Basin (Lagarto, Salgado, Boquim, and Estância/Sergipe), and in other cities in the state of Sergipe (SE), where these plants occur naturally. The collections were carried out, in 2011, directly in different mother trees previously selected, respecting the minimum distance of $50 \mathrm{~m}$ as indicated by Bianchetti (1999). Subsequently, we transported the fruits to the Forest Nursery of the Federal University of Sergipe, where they were dried in the shade and processed. Then, we separated the seeds into lots, composed of different matrices, which were packed in transparent waterproof plastic bags, labeled and stored since 2011, in a cold chamber at the Department of Forest Sciences-UFS, at a temperature of $6-9{ }^{\circ} \mathrm{C}$ and $60-65 \%$ relative air humidity, where they remained until the time of use in this study.

\section{Evaluation of physical and morphometric characteristics of seeds}

For the evaluation of the physical quality of the seeds, the morphometry of 100 seeds of each species of the same batch was initially performed, with the aid of a digital caliper $(0.01 \mathrm{~mm})$ of the brand Digimess YT202, obtaining values of length, width, and thickness $(\mathrm{mm})$. Also, evaluations of a specific mass, weight of a thousand seeds, and the number of seeds per kilogram $(\mathrm{kg})$ were carried out using a precision $120 \mathrm{~g}$ analytical balance with a $0.0001 \mathrm{~g} \mathrm{BEL}$ brand resolution and calculated according to the recommendations of the Seed Analysis Rules (BRASIL, 2009).

The humidity degree of the seeds of the selected species, using four repetitions of 25 seeds, which were placed in aluminum capsules, weighed, and then dried in an oven at $105 \pm 2{ }^{\circ} \mathrm{C}$, for $24 \mathrm{~h}$. The humidity calculation was performed according to Brasil (2009) through the expression:

Where:

$$
U(\%)=100 .(P-p) /(P-t)
$$

P: initial weight - the weight of the container and its lid, plus the weight of the moist seed;

P: final weight - the weight of the container and its lid, plus the weight of the moist seed;

$\mathrm{t}$ : tare - the weight of the container with its lid.

\section{Treatments to overcome dormancy}

The species used show integumentary dormancy, and thus, treatment was used to facilitate water absorption and provide maximum germination. Thus, all species were subjected to chemical scarification through concentrated sulfuric acid (PA 95-98\%), each with a specific immersion time (Table 1).

FLORESTA, Curitiba, PR, v. 51, n. 2, p. 255-262, abril/jun 2021.

Jesus, J. B. et.al.

ISSN eletrônico 1982-4688 
Table 1. Recommendations used to overcome seed dormancy for the studied species.

Tabela 1. Recomendações utilizadas para a superação da dormência de sementes das espécies estudadas.

\begin{tabular}{lccc}
\hline \multicolumn{1}{c}{ Species } & Treatment & $\begin{array}{c}\text { Immersion } \\
\text { time (min) }\end{array}$ & Recommendations \\
\hline Cassia grandis & sulphuric acid & 30 & Melo and Rodolfo Júnior (2006) \\
Enterolobium contortisiliquum & sulphuric acid & 25 & Silva et al. (2012) \\
Guazuma ulmifolia & sulphuric acid & 50 & Ribeiro et al. (2012) \\
Libidibia ferrea var. leiostachya & sulphuric acid & 25 & Biruel et al. (2007) \\
\hline
\end{tabular}

Soon after immersion, the seeds were washed with distilled water for approximately 10 min to remove the acid. The entire process was carried out at the Forest Seeds Laboratory of the Department of Forest Sciences UFS.

\section{Evaluation of the physiological quality of seeds}

The determination of the initial viability of the seeds was carried out through a germination test, according to the Rules for Seed Analysis (BRASIL, 2009), using four replications of 25 seeds. The seeds were disinfected with $2 \%$ sodium hypochlorite for two minutes, followed by washing in distilled water to avoid a microorganism's infestation.

The germination tests were carried out in a germination chamber of the BOD type, with a temperature of $25^{\circ} \mathrm{C}$, under continuous white light. The substrate was sand (washed, sieved, and sterilized in an oven at $120^{\circ} \mathrm{C}$ for $24 \mathrm{~h}$ ). The small seeds were sown on a substrate in plastic boxes $(11 \times 11 \times 2.5 \mathrm{~cm})$. The large seeds were sown in plastic trays $(26.5 \times 17.5 \times 5.5 \mathrm{~cm})$. Whenever necessary, the substrate was moistened to keep the seeds in moisture conditions favorable to germination and seedling development. After the assembly of the germination tests, the evaluations were carried out every two days, counting the seeds with root emissions and considering the normal seedlings that had primary root, hypocotyl, cotyledons, epicotyl, and open photophilous to be germinated. The duration of the tests varied for each species studied, as indicated by the Instructions for Analysis of Seeds of Forest Species (BRASIL, 2013), and the species absent in the document was evaluated up to 40 days after the beginning of the test. At the end of the tests, the non-germinated seeds were classified as dormant, hard, or deteriorated seeds (BRASIL, 2009).

\section{Implementation and evaluation of the emergency via direct seeding}

The experiment, in the field, was implemented on July 2, 2014, in a stretch on the right and left banks of the Piauitinga River watercourse, in the Brasília village, Lagarto municipality, Sergipe state, between the UTM Sirgas coordinates 2000, South 24 spindle: 657800/8793400 and 658000/8793200. The predominant forms of land use and occupation before the study were pasture and agriculture. In the area, cleaning was carried out using manual weeding, eliminating invasive plants without initial soil preparation. Isolation of the experiment areas selected for planting was carried out through the construction of barbed wire fences to avoid the entry of animals present in the surroundings.

Using the Randomized Block Design (RBD) to test the seeds with the treatment to overcome dormancy in the four species used, in four blocks, with sowing taking place by selecting two stretches of the riparian forest area, at an approximate distance of $300 \mathrm{~m}$, each disposed on each bank of the river and each bank there was a distance of $3 \mathrm{~m}$ from one block to the other. Each experimental block had 10 lines, composing 10 pits $(30 \times 30 \mathrm{x}$ $30 \mathrm{~cm}$, and using this depth dimension to remove possible layers of soil impediment), in $2.0 \times 1.0 \mathrm{~m}$ spacing, with the factorial scheme distribution done by random drawing for each line.

For Libidibia ferrea var. leiostachya, 20 seeds per hole were used, and for the other species, 10 seeds per hole. The seeds of Cassia grandis, Enterolobium contortisiliquum, and Libidibia ferrea var. leiostachya were sown at $1.5 \mathrm{~cm}$, and Guazuma ulmifolia at $1.0 \mathrm{~cm}$, depending on their size. To favor the initial development of the species and reduce the competition for light, water, and nutrients, each pit was crowned with a minimum radius of $50 \mathrm{~cm}$ in the to be sown area, with manual cleaning at each evaluation of the seedling emergence in the field. The control of leaf-cutting ants was performed using granulated bait formicide when the need for assessments was verified.

Seedling emergence assessments were carried out weekly during 90 days after sowing, considering seedlings that showed visible protophils emerged, with the results expressed as a percentage and calculated according to the total number of seeds sown by species, considering the percentage according to the number of seeds emerged for each species, at weekly intervals.

FLORESTA, Curitiba, PR, v. 51, n. 2, p. 255-262, abril/jun 2021.

Jesus, J. B. et.al.

ISSN eletrônico 1982-4688

DOI: $10.5380 /$ rf.v51 i2. 58181 


\section{Statistical analysis}

The results regarding both physical and morphometric evaluations of the seeds and seedling germination (considering normal seedlings), performed in the laboratory, as well as the field emergence, were analyzed for the normality of errors and homogeneity of variances, expressed as a percentage and calculated according to the total number of seeds sown per species. The treatment averages were transformed into a square root sinus of $x / 100$ when necessary. The results were subjected to analysis of variance using the F test and the means compared by Scott-Knott at 5\% in the SISVAR ${ }^{\circledR}$ program (FERREIRA, 2011).

\section{FINDINGS}

The physical and morphometric characteristics of the studied species are shown in Table 2. Considering the mass of the seeds, it was observed that Gulmifolia had the lowest average $(0.0049 \mathrm{~g})$. On the other hand, the other species showed statistically different mass values, with E. contortisiliquum $(0.7167 \mathrm{~g})$ with greater mass, respectively, followed by $C$. grandis $(0.6862 \mathrm{~g})$ and $L$. ferrea var. leiostachya $(0.2211 \mathrm{~g})$.

Table 2. Physical and morphometric characteristics of seeds of forest species. M - mass, WTS - weight of a thousand seeds, NS - number of seeds per kilogram, M - moisture, L - length, W - width, and T thickness.

Tabela 2. Características físicas e morfométricas de sementes de espécies florestais. M - Massa, PMS - peso de mil sementes, $\mathrm{NS}$ - número de sementes por quilograma, $\mathrm{U}$ - umidade, $\mathrm{C}$ - comprimento, $\mathrm{L}$ - largura e E - espessura.

\begin{tabular}{lccccccc}
\hline \multirow{2}{*}{ Species } & \multicolumn{7}{c}{ Evaluated parameters } \\
\cline { 2 - 8 } & $\mathbf{M}(\mathbf{g})$ & $\mathbf{W T S}(\mathbf{g})$ & $\mathbf{N S} / \mathbf{k g}$ & $\mathbf{M}(\%)$ & $\mathbf{L}(\mathbf{m m})$ & $\mathbf{W}(\mathbf{m m})$ & $\mathbf{T}(\mathbf{m m})$ \\
\cline { 2 - 8 } Cassia grandis & $0.6862 \mathrm{c}$ & $681,498 \mathrm{c}$ & $1,461 \mathrm{a}$ & $16.56 \mathrm{c}$ & $17,261 \mathrm{~d}$ & $11,325 \mathrm{~d}$ & $4,398 \mathrm{~b}$ \\
\hline $\begin{array}{l}\text { Enterolobium } \\
\text { contortisiliquum }\end{array}$ & $0.7167 \mathrm{~d}$ & $705,051 \mathrm{~d}$ & $1,421 \mathrm{a}$ & $16.60 \mathrm{c}$ & $15,965 \mathrm{c}$ & $10.225 \mathrm{c}$ & $6,735 \mathrm{c}$ \\
\hline $\begin{array}{l}\text { Guazuma } \\
\text { ulmifolia }\end{array}$ & $0.0049 \mathrm{a}$ & $4.963 \mathrm{a}$ & $201,614 \mathrm{c}$ & $5.03 \mathrm{a}$ & $2.606 \mathrm{a}$ & $1,994 \mathrm{a}$ & $1,563 \mathrm{a}$ \\
\hline $\begin{array}{l}\text { Libidibia ferrea } \\
\text { var. leiostachya }\end{array}$ & $0.2211 \mathrm{~b}$ & $222.654 \mathrm{~b}$ & $4.521 \mathrm{~b}$ & $6.70 \mathrm{~b}$ & $10,710 \mathrm{~b}$ & $6,825 \mathrm{~b}$ & $4,33 \mathrm{~b}$ \\
\hline \multicolumn{1}{c}{ CV $(\%)$} & 4,56 & 1,05 & 0,59 & 4,45 & 1,1 & 2,62 & 3,51 \\
\hline
\end{tabular}

Averages followed by the same letter in the columns do not differ by the Scott-Knott cluster test at $5 \%$ probability.

Regarding the weight of a thousand seeds, it was observed that all species differed statistically, with emphasis on Guazuma ulmifolia, which had the lowest value (4.963 g), due to their small specific mass, thus resulting in the greatest number of seeds per kilo $(201,614)$. The highest weight of a thousand seeds obtained was for E. contortisiliquum $(705,051 \mathrm{~g})$, the same species that had the highest mass, consequently with the lowest number of seeds per kilo $(1,421)$. However, it is noteworthy that $C$. grandis $(681,498 \mathrm{~g})$, despite having a lower weight of a thousand seeds than $C$. contortisiliquum, has a statistically similar number of seeds per kilo $(1,461)$. The species L. ferrea var. leiostachya and G. ulmifolia presented values of seeds per kilo that differ statistically from the other species, with G. ulmifolia presenting the second largest number $(201,614)$, followed by L. ferrea var. leiostachya (4.521).

As for the moisture degree in the studied species seeds, it was found that G. ulmifolia had the lowest value (5.03\%), and L. ferrea var. leiostachya also had a low value (6.70\%), the species differed in the averages test, while $C$. grandis and E. contortisiliquum had the highest moisture content, with $16.56 \%$ and $16.59 \%$, respectively, being statistically similar and differing from other species.

Concerning the length and width of the seeds, all species differed statistically, with $C$. grandis presenting the largest length $(17.261 \mathrm{~cm})$ and width $(11.325 \mathrm{~cm})$. As for the thickness, E. contortisiliquum obtained a higher thickness value $(6.735 \mathrm{~cm})$, differing from the other species, followed by $C$. grandis $(4.398 \mathrm{~cm})$ and L. ferrea var. leiostachya $(4.33 \mathrm{~cm})$ that did not statistically differ from each other. G. ulmifolia presented the lowest values of length $(2.606 \mathrm{~cm})$, width $(1.994 \mathrm{~cm})$, and thickness $(1.563 \mathrm{~cm})$, with its mean different from the other species regarding these parameters.

For the analysis of physiological quality, it was observed that in the studied species, the percentage of radicles emission of $C$. grandis (97\%) and E. contortisiliquum (90\%) were higher than the other species, however, being statistically similar to each other (Table 3 ). Cassia grandis was the only species not to have hard seeds, being different from all others, even L. ferrea var. leiostachya and E. contortisiliquum presenting low values, 15 and $9 \%$, respectively, and being statistically similar. G. ulmifolia obtained the highest percentages of hard seeds,

FLORESTA, Curitiba, PR, v. 51, n. 2, p. 255-262, abril/jun 2021.

Jesus, J. B. et.al.

ISSN eletrônico 1982-4688

DOI: $10.5380 /$ rf.v51 i2. 58181 
with $41 \%$. For deteriorated seeds, we observed a high percentage in L. ferrea var. leiostachya (56\%), followed by G. ulmifolia (21\%), while C. grandis and Enterolobium contortisiliquum had the lowest values, with $3 \%$ and $1 \%$, respectively, similar by the test average and different from other species.

Table 3. Physiological quality (\%) of seeds of forest species regarding radicle emission (RE), hard seeds (Ha), deteriorated seeds (De), and normal seedlings (NS) in the laboratory, and the seedling field emergence (SFE).

Tabela 3. Qualidade fisiológica (\%) de sementes de espécies florestais quanto à emissão de radícula (ER), sementes duras (Du), sementes deterioradas (De) e plântulas normais (PN) em laboratório, e da emergência em campo das plântulas (EP).

\begin{tabular}{lccccc}
\hline & & Laboratory analysis & & Field \\
\hline Species & RE $(\%)$ & Ha $(\%)$ & De $(\%)$ & NS (\%) & SFE (\%) \\
\hline Cassia grandis & $97.00 \mathrm{~b}$ & $0,00 \mathrm{a}$ & $3,00 \mathrm{a}$ & $79.00 \mathrm{cA}$ & $69.25 \mathrm{cA}$ \\
Enterolobium contortisiliquum & $90.00 \mathrm{~b}$ & $9,00 \mathrm{~b}$ & $1,00 \mathrm{a}$ & $83,00 \mathrm{cB}$ & $20.00 \mathrm{aA}$ \\
Guazuma ulmifolia & $38.00 \mathrm{a}$ & $41,00 \mathrm{c}$ & $21,00 \mathrm{~b}$ & $35.00 \mathrm{bA}$ & $26,50 \mathrm{aA}$ \\
Libidibia ferrea var. leiostachya & $29,00 \mathrm{a}$ & $15,00 \mathrm{~b}$ & $56,00 \mathrm{c}$ & $22,00 \mathrm{aA}$ & $44.75 \mathrm{bA}$ \\
\hline Average germination and emergence $(\%)$ & - & - & - & $51.70 \mathrm{~A}$ & $32,10 \mathrm{~A}$ \\
\hline \multicolumn{1}{c}{ CV $(\%)$} & 13,29 & 26,3 & 25,14 & 13,01 & 32,10 \\
\hline
\end{tabular}

Averages followed by the same letter in the columns do not differ by the Scott-Knott cluster test at 5\% probability.

Lower case letters compare between species. Capital letters compare germination and emergence in each species.

The percentage of normal seedlings was similar in C. grandis and E. contortisiliquum, with 79 and $83 \%$, respectively. The lowest value was obtained in L. ferrea var. leiostachya (22\%), following and differing statistically from G. ulmifolia with $35 \%$. Concerning field emergence, $C$. grandis had the highest value with $69.25 \%$, differing from all species, followed by L. ferrea var. leiostachya (44.75\%). G. ulmifolia and E. contortisiliquum with $26.5 \%$ and $20 \%$ respectively were statistically equal.

Comparing germination in the laboratory with the emergence in the field, statistically, similar averages are observed for the species C. grandis, G. ulmifolia, and L. ferrea var. leiostachya. E. contortisiliquum presented statistical difference, emphasizing the difference between the averages of $83 \%$ of germination and $20 \%$ of emergence.

\section{DISCUSSION}

The morphometric characteristics of the seeds are highlighted in the emergence process of the initial parts of the plant this is due to the large seeds having a higher number of accumulated reserves that will be required for the development of the embryonic axis and subsequent establishment of the seedlings (SANTOS et al., 2012). According to Carvalho and Nakagawa (2012), the higher the density of the seed, the greater its vigor. Therefore, species belonging to genera and botanical families, as well as different ecological groups, are expected to have different physical and morphometric parameters (BUDOWSKI, 1965). However, although the averages were considered within the same species, the values regarding seed morphometry are variable even within the same species, and this can be seen when comparing the same parameters with other studies, such as E. contortisiliquum presented values higher than those seen by Barreto and Ferreira (2011) with $13.5 \mathrm{~mm}, 9.5 \mathrm{~mm}$ and $0.66 \mathrm{~mm}$, as well as for $C$. grandis with values of $15.83 \mathrm{~mm}, 11.34 \mathrm{~mm}$ and $6.39 \mathrm{~mm}$ (BEZERRA et al., 2012), for length, width, and thickness, respectively, in both comparisons.

As for the size of the seeds, Doust et al. (2006) observed that the larger seeds (> $5.0 \mathrm{~g})$, which were categorized based on the weight, showed higher rates of establishment than the small seeds $(0.01 \mathrm{~g}$ to $0.099 \mathrm{~g})$ and intermediate $(0,1$ to $4.99 \mathrm{~g})$, noting that this parameter was one of the factors that influenced the establishment of seedlings of sixteen tree species used to restore tropical forests via direct seeding in Northeast Queensland, Australia. Similar behavior was observed in the field by Ferreira et al. (2009) when performing riparian forest recovery activity in the Lower São Francisco-SE with five forest species (L. ferrea var. leiostachya, C. grandis, E. contortisiliquum, Hymenaea courbaril, and Schinus terebinthifolia) also via direct seeding. In this study, the authors found that seeds of greater specific mass and larger size showed a faster emergence and a higher survival rate at 90 days after sowing. Such results can be explained, as the authors themselves mention, by the higher number of accumulated reserves contained in the seeds of larger sizes and weights.

FLORESTA, Curitiba, PR, v. 51, n. 2, p. 255-262, abril/jun 2021.

Jesus, J. B. et.al.

ISSN eletrônico 1982-4688

DOI: $10.5380 /$ rf.v51 i2. 58181 
Regarding the weight of the seeds, lower values were observed when compared to other studies, such as $7.6 \mathrm{~g}$ for the weight of a thousand seeds of G. ulmifolia (PAIVA SOBRINHO; SIQUEIRA, 2008) and $0.867 \mathrm{~g}$ of mass-specific to $C$. grandis, observed by Bezerra et al. (2012). Such variation is still verified, comparing the results of the present work with those of three species in common to the study by Ferreira et al. (2009), where E. contortisiliquum and L. ferrea var. leiostachya presented lower values for all parameters compared to those indicated in the present study. Cassia grandis presented higher values for specific mass $(0.753 \mathrm{~g})$. The variation in weight can be conditioned not only to the mass and the reserve content but also to the tree-matrix quality. Besides, this variation may also depend on the water content in the seed, which, in turn, may be related to its drying and storage process.

The relative humidity value can also directly affect the weight of a thousand seeds and the number of seeds per kilo results. This is proven when comparing the results obtained by Santos et al. (2012) for G. ulmifolia, which in its study had a percentage of 5.37, giving higher values also for the weight of a thousand seeds (5.93 g), and the number of seeds per kilo (168.634), these are the consequence of the specific mass that was probably greater than the seeds of the present study. Additionally, the higher water content may be related to the storage time until the date used, which was lower than the present. Such results are different from those obtained in the present work. Another factor is the variations in the seed's water content, which can influence its germinative capacity, observed in $C$. grandis and $E$. contortisiliquum seeds, which had similar values with a similar response in the laboratory, but, in the field, the answer was not the same. The seeds with lower relative humidity had lower germination values. Besides, the variation in the seeds water content can give different germination percentages when analyzed together with the drying carried out and the form of storage. Nery et al. (2014) analyzed two species considered physiologically orthodox (Casearia sylvestris and Eremanthus incanus), two recalcitrant (Guarea kunthiana and Protium heptaphyllum), and one intermediate (Qualea grandifl). Even though the species used in the present study are orthodox, it was found that the water content in the seed was different between species, which may indicate that the germination percentages in the laboratory may be related to this attribute. In the field, soil moisture may have negatively affected $E$. contortisiliquum, showing its sensitivity to this environmental condition.

The response of the physiological quality of the studied seeds indicated a high root emission of $C$. grandis (97\%) and E. contortisiliquum (90\%), a result of C. grandis superior to that obtained by Melo and Rodolfo Júnior (2006), who found $72 \%$. In contrast, Lessa et al. (2014) acquired more than $95 \%$ germination when studying $E$. contortisiliquum, a percentage also higher than the almost $60 \%$ obtained by Silva et al. (2012). This variation can be expected considering, as previously mentioned, the other factors that can determine the germination capacity, in addition to its vigor and the quality of the chosen parent trees that make up the lots used. The other species obtained low values of radicle emission, which are statistically similar to each other, with emphasis on $L$. ferrea var. leiostachya with the lowest value (29\%), a value lower than that found by Biruel et al. (2010) that obtained $57 \%$ germination, a difference associated with the high value of deteriorated seeds obtained in the present study.

The difference between the sources of variation (germination x field) is also verified by Guedes et al. (2015), who, when working on Amburana cearensis, observed a higher germination average of this species in the laboratory. However, in one of the used lots, they found a higher percentage for emergence in the field concerning germination. Dutra et al. (2016) also obtained higher values of field emergency compared to laboratory results for all treatments on different substrates used. This condition of higher emergence in the species field coincides with that seen in the present study, only for L. ferrea var. leiostachya, which had a field emergency (44.75\%) higher than germination in the laboratory $(22 \%)$. A higher percentage of emergence is an answer to be expected when compared to germination in a controlled environment, where it allows adequate substrate, temperature, humidity, and luminosity for maximum germination capacity for each species. In the field, environmental factors are adverse, with seedlings emerging that are more tolerant to each natural condition.

The seed size is highlighted by Biruel et al. (2010), who affirm that, generally, small seeds present lower values of germination and vigor when compared with those of medium and large size. This may also be related to the present study where the species of smaller seeds (G. ulmifolia) had a low emergence in the field, and C. grandis, which has greater length and width and presented the highest emergence among species. However, $E$. contortisiliquum, which despite having a higher average mass and thickness of its seeds among the other species, had a low average of emergence, in addition to having the second-best radicle emission rate (90\%), and normal seedlings $(83 \%)$ had the least emergency in the field with only $20 \%$. This condition may be related to seed sensitivity without cutaneous resistance, since it was treated to remove this dormancy, to environmental factors in the riparian region, mainly humidity, causing its embryo deterioration or death.

One factor to be taken into account is the resistance of seeds to high levels of soil moisture and their influence on the emergence in the field of the species used, as an accumulated value of $266.75 \mathrm{~mm}$ was recorded in July in the rainy season Boquim-SE, about $28 \mathrm{~km}$ from the studied area (nearest data collection point). On the 16 th of the same month, the highest rainfall $(135.5 \mathrm{~mm})$ was recorded, which increased species mortality, deteriorated seeds, or promoted the displacement of the soil mass.

FLORESTA, Curitiba, PR, v. 51, n. 2, p. 255-262, abril/jun 2021.

Jesus, J. B. et.al.

ISSN eletrônico 1982-4688

DOI: $10.5380 /$ rf.v51 i2. 58181 


\section{CONCLUSIONS}

- Cassia grandis, Enterolobium contortisiliquum, and Libidibia ferrea var. leiostachya have the highest weights, lengths, widths, and thicknesses among the species studied, and Guazuma ulmifolia with the lowest mass and, consecutively, the highest number of seeds per kilo.

- C. grandis and E. contortisiliquum have the highest values of humidity, radicle emission, and normal seedlings, while Libidibia ferrea var. leiostachya presents a high percentage of deteriorated seeds and Guazuma ulmifolia the lowest percentage of normal seedlings.

- The species showed higher percentages of germination under controlled conditions when compared to field emergence, except for L. ferrea var. leiostachya, which had the highest emergency in the field. C. grandis stood out with high percentages both in the laboratory and in the field, while E. contortisiliquum even with a higher germination percentage, did not show the same response in the field.

\section{REFERENCES}

BARRETO, S. S. B.; FERREIRA, R. A. Aspectos morfológicos de frutos, sementes, plântulas e mudas de Leguminosae Mimosoideae: Anadenanthera colubrina (Vellozo) Brenan e Enterolobium contortisiliquum (Vellozo) Morong. Revista Brasileira de Sementes, Londrina, v. 33, p. 223 - 232, 2011.

BEZERRA, F. T. C.; ANDRADE, L. A.; BEZERRA, M. A. F.; PEREIRA, W. E.; FABRICANTE, J. R.; OLIVEIRA, L. S. B.; FEITOSA, R. C. Biometria de frutos e sementes e tratamentos pré-germinativos em Cassia grandis L. f. (Fabaceae). Semina: Ciências Agrárias, Londrina, v. 33, p. 2863 - 2876, 2012.

BIANCHETTI, A. Produção de sementes florestais. Macapá: Embrapa Amapá, 1999. 38 p.

BIRUEL, R. P.; AGUIAR, I. B. de; PAULA, R. C. de. Germinação de sementes de pau-ferro submetidas a diferentes condições de armazenamento, escarificação química, temperatura e luz. Revista Brasileira de Sementes, Londrina, v. 29, p. 151 - 159, 2007.

BIRUEL, R. P.; PAULA, R. C. de; AGUIAR, I. B. de. Germinação de sementes de Caesalpinia leiostachya (Benth) Ducke (pau-ferro) classificadas pelo tamanho e pela forma. Revista Árvore, Viçosa, v. 34, p. 197 - 204 , 2010.

BRASIL. Regras para análise de sementes. Brasília: Ministério da Agricultura, Pecuária e Abastecimento, 1 ed. 2009, 399 p.

BRASIL. Instruções para Análise de Sementes de Espécies Florestais. Brasília: Ministério da Agricultura, Pecuária e Abastecimento, 2013, 97 p.

BUDOWSKI, G. N. Distribution of tropical American rain forest species in the light of succession processes. Turrialba, v. 15, n. 1, p. 40 - 2, 1965.

CARVALHO, N. M. de; NAKAGAWA, J. Sementes: ciência, tecnologia e produção. Jaboticabal: Funep, 5 ed. 2012, $590 \mathrm{p}$.

DOUST, S. J.; ERSKINE, P. D.; LAMB, D. Direct seeding to restore rainforest species: microsites effects on the early establishment and growth of rainforest tree seedlings on degraded land in the wet tropics of Australia. Forest Ecology and Management, v. 234, p. 333 - 343, 2006.

DUTRA, A. F.; ARAUJO, M. M.; RORATO, D. G.; MIETH, P. Germinação de sementes e emergência de plântulas de Luehea divaricata Mart. et. Zucc. em diferentes substratos. Ciência Florestal, Santa Maria, v. 26, n. 2, p. 411 - 418, 2016.

FERREIRA, D. F. Sisvar: a computer statistical analysis system. Ciência e Agrotecnologia, v. 35, n. 6, p. 1039 1042, 2011.

FERREIRA, R. A.; SANTOS, P. L.; ARAGÃO, A. G.; SANTOS, T. I. S.; SANTOS NETO, S. E. M.; REZENDE, M. A. S. Semeadura direta com espécies florestais na implantação de mata ciliar no Baixo São Francisco em Sergipe. Scientia Forestalis, Piracicaba, v. 37, n. 81, p. 37 - 46, 2009.

FLORES, A. V.; BORGES, E. E. L.; GONÇALVES, J. F. C.; GUIMARÃES, V. M.; ATAÍDE, G. M.; BARROS, D. P.; PEREIRA, M. D. Efeito do substrato, cor e tamanho de sementes na germinação e vigor de Melanoxylon brauna. Pesquisa Florestal Brasileira, Colombo, v. 34, p. 141 - 147, 2014.

FLORESTA, Curitiba, PR, v. 51, n. 2, p. 255-262, abril/jun 2021.

Jesus, J. B. et.al.

ISSN eletrônico 1982-4688

DOI: $10.5380 /$ rf.v51 i2. 58181 
GUEDES, R. S.; ALVES, E. U.; VIANA, J. S.; GONÇALVES, E. P.; LiMA, C. R.; SANTOS, S. R. N. Germinação e vigor de sementes de Apeiba tibourbou submetidas ao estresse hídrico e diferentes temperaturas. Ciência Florestal, Santa Maria, v. 23, p. 45 - 53, 2013.

GUEDES, R. S.; ALVES, E. U.; SANTOS-MOURA, S. DA S.; GALINDO, E. A. Teste de comprimento de plântula na avaliação da qualidade fisiológica de sementes de Amburana cearensis (Allemão) A.C. Smith. Semina: Ciências Agrárias, Londrina, v. 36, n. 4, p. 2373 - 2382, 2015.

LESSA, B. F. T.; ALMEIDA, J. P. N.; PINHEIRO, C. L.; NOGUEIRA, F. C. B.; MEDEIROS FILHO, S. Germinação e crescimento de plântulas de Enterolobium contortisiliquum (Vell.) Morong em função da localização da semente no fruto e regimes de temperatura. Bioscienci Journal, Uberlândia, v. 30, p. 1474 - 1483 , 2014.

MELO, R. R.; RODOLFO JÚNIOR, F. Superação de dormência em sementes e desenvolvimento inicial de canafístula (Cassia grandis L.f.). Revista Científica Eletrônica de Engenharia Florestal, v. 4, n. 7, 2006. Disponível em: <http://faef,revista,inf,br/imagens_arquivos/arquivos_destaque/VhNy33UMoIclb8f_2013-4-2517-55-40,pdf >. Acesso em: 15 jan. 2014.

NERY, M. C.; DAVIDE, A. C.; SILVA, E. A. A.; SOARESM, G. C. M.; NERY, F. C. Classificação fisiológica de sementes florestais quanto a tolerância à dessecação e ao armazenamento. CERNE, Lavras, v. 20, p. 477 - 483 , 2014.

PAIVA SOBRINHO, S.; SIQUEIRA, A. G. de. Caracterização morfológica de frutos, sementes, plântulas e plantas jovens de mutamba (Guazuma ulmifolia Lam. - Sterculiaceae). Revista Brasileira de Sementes, Londrina, v. 30, p. $114-120,2008$.

RIBEIRO, E. S.; OLIVEIRA, D. P.; SOUZA, R. S.; PASA, M.C.; SOUZA, R. A. T. C. Efeito da temperatura na germinação de sementes de Enterolobium contortisiliqunn (Vell,) Morong - (Mimosoidae) e Guazuma ulmifolia (Sterculiaceae). Biodiversidade, Rondonópolis, v. 11, p. 23 - 30, 2012.

SANTOS, P. L.; FERREIRA, R. A.; ARAGÃO, A. G.; AMARAL, L. A.; OLIVEIRA, A. Estabelecimento de espécies florestais nativas por meio de semeadura direta para recuperação de áreas degradadas. Revista Árvore, Viçosa, v. 36, p. 237 - 245, 2012.

SILVA, A. C. F.; SILVEIRA, L. P.; NUNES, I. G.; SOUTO, J. S. Superação de dormência de Enterolobium contortisiliquum Mor. (Vell.) Morong. Scientia Plena, São Cristóvão, v. 8, p. 1 - 6, 2012.

SILVA, K. de A.; MARTINS, S. V.; MIRANDA NETO, A.; CAMPOS, W. H. Semeadura direta com transposição de serapilheira como metodologia de restauração ecológica. Revista Árvore, v. 39, n. 5, p. 811 - 820, 2015.

SIlVA, K. B.; AlVES, E. U.; OlIVEIRA, A. N. P.; RODRIGUES, P. A. F.; SOUSA, N. A.; Aguiar, V. A. Variabilidade da germinação e caracteres de frutos e sementes entre matrizes de Sideroxylon obtusifolium (Roem. \& Schult.) T.D. Penn. Revista Eletrônica de Biologia, Sorocaba, v. 7, p. 281 - 300, 2014. 